\title{
Level of serum beta carotene and its association with lumbar osteophyte formation
}

\author{
N. Selvam ${ }^{1, *}$, Raju Babu Rapeta ${ }^{2}$ \\ ${ }^{1}$ Professor, ${ }^{2}$ Assistant Professor, Dept. of Orthopaedics, Sri Venkateswaraa Medical College and Research Centre, Ariyur - \\ Pondicherry, India
}

*Corresponding Author: N. Selvam

Email: drnselvam@rediffmail.com

\begin{abstract}
Introduction: Cause of chronic low back pain in persons over the age of 50 years include degenerative diseases like osteoarthritis of spine and spinal canal stenosis. Osteoarthritis of spine is a degenerative process ${ }^{19-30}$ identified radiologically by joint space reduction, marginal osteophytes and sub-chondral sclerosis. Nathan et $\mathrm{al}^{3}$ classified significantly osteophyte positive if more than SIX osteophytes are found from L1 / L2 to L5 /S1 vertebrae in the lumbar spine X-rays.

Serum beta carotene is a carotenoid, which has anti-oxidant effect ${ }^{35-37}$ by increasing Glutathione levels in cells. Normal serum beta carotene level ranges from $0.74 \mathrm{nmol} / \mathrm{ml}$ to $3.72 \mathrm{nmols} / \mathrm{ml}$. Based on literature, higher serum beta carotene levels are shown to halt the progression of many diseases including cardiac diseases ${ }^{38,39}$ and degenerative changes in knee joint. But so far only a single study is available to co-relate the levels of serum beta carotene and lumbar spine osteophytes. Hence this study was done.

Materials and Methods: This study was conducted at JIPMER, Pondicherry, from August 2015 to March 2017. It was conducted as OP procedure. 153 patients of over 50 years of year who complained of low back pain of more than 3 months duration were selected. Their personal history regarding alcohol drinking and smoking noted. Radiographs of lumbar spine A.P. and lateral views were taken. They were divided into osteophyte positive or negative as defined by Nathan. ${ }^{3}$ These patients' serum beta carotene levels were assessed. The level of serum beta carotene and its relationship with lumbar spine osteophyte formation was analysed. Results: Females predominated study $67 \%$ of patients were osteophyte negative and $33 \%$ were positive. $74 \%$ of osteophyte positive patients had serum beta carotene less than $0.7 \mathrm{nmol} / \mathrm{ml}$ and $26 \%$ had more than that. But, nearly all $98 \%$ of osteophyte negative had more than $0.7 \mathrm{nmol} / \mathrm{ml}$ of serum beta carotene, showing that the lumbar osteophyte formation is inversely proportional to the level of serum beta carotene levels. Our statistics also showed that there is a strong association between alcohol consumptions and smoking with lumbar osteophyte formation.

Conclusion: Our study showed that low serum beta carotene levels predisposed and increased lumbar osteophyte formation. It also showed strong association between Alcohol consumption and Tobacco use with lumbar osteophyte formation.
\end{abstract}

Keywords: Lumbar osteophyte, Serum beta carotene, Degenerative osteoarthritis, Alcohol consumption, Tobacco use, Chronic low back pain.

\section{Introduction}

Chronic low back ${ }^{5-12}$ affects 60 to $85 \%$ of adults in their life time. Definition of chronic low back pain is pain persisting for more than three consecutive months without pain free period - Van Geen et al. ${ }^{1}$ Causes of chronic low back pain in persons of more than 50 years of age include osteoarthritis of spine and spinal canal stenosis. Osteoarthritis of spine is defined radiologically by joint narrowing, osteophytes and sub-chondral sclerosis. (O’Neill TW et al. ${ }^{2}$ )
Osteophyte formation is a physiological response to load bearing, alteration in oxygen tension and fluid dynamic pressure. ${ }^{13-17}$

There are two types of osteophytes: 1 . Spondylosis deformans and 2. Inter-vertebral osteochondrosis.

Spondylosis deformans is a bony outgrowth that arises from anterior and lateral perimeters of the vertebral end plate apophyses. They occur due to stress of annular ligament and seen at lumbar 3 level and has no effect on vertebral height and is usually asymptomatic..$^{11,13-17}$
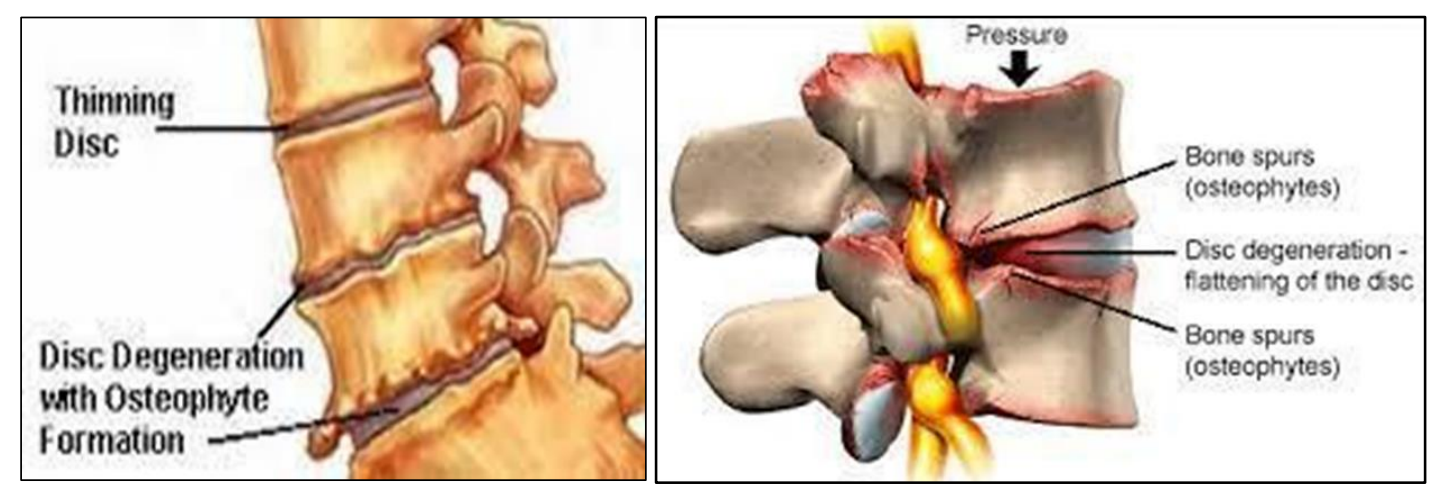

Fig. 1 


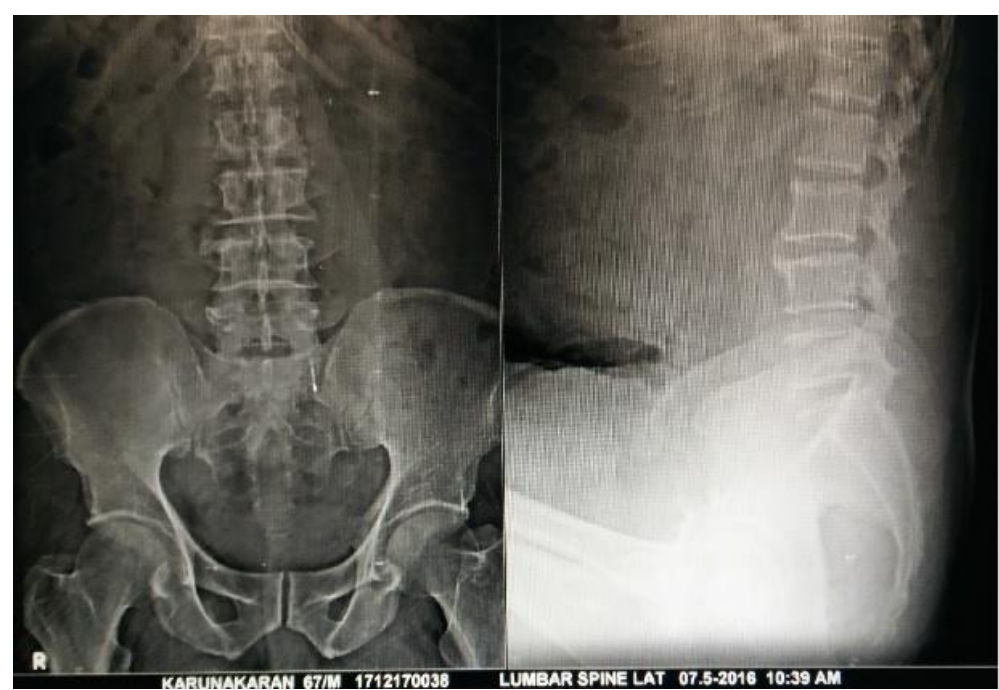

Fig. 2: Lumbar spine osteophytes - Moderate

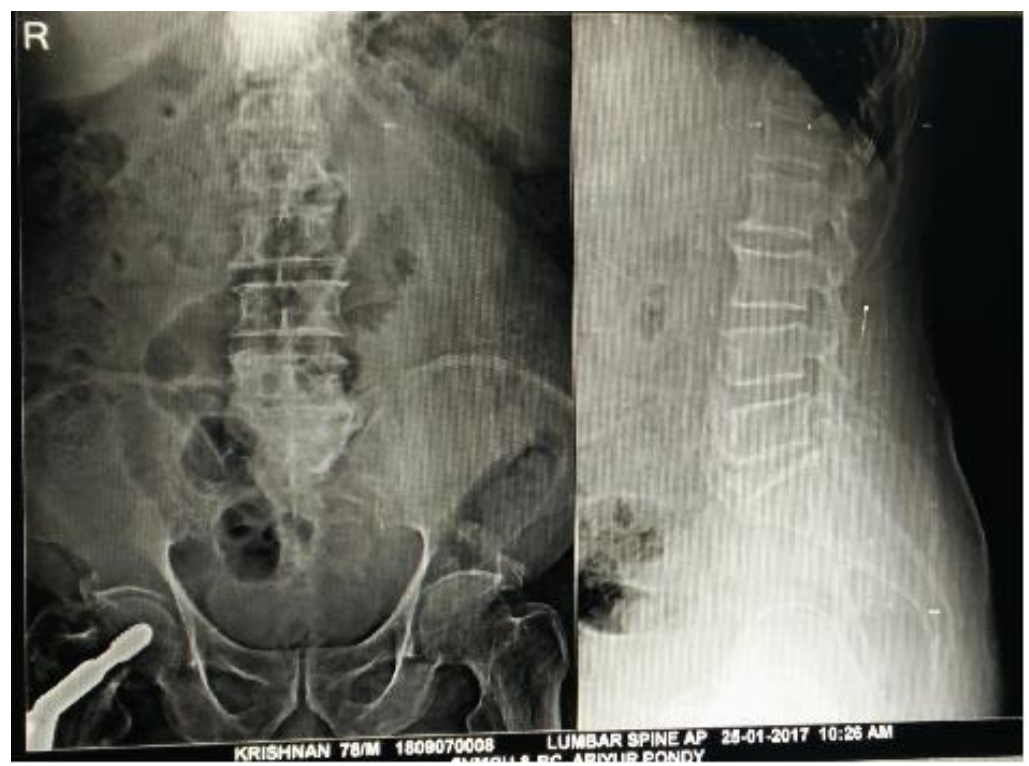

Fig. 3: Lumbar spine osteophytes -Severe-

The second category-inter- vertebral osteochondrosis are more aggressive with end plate osteophytes and disc space narrowing. If they protrude into spinal canal they may cause radiculopathy or spinal canal stenosis.

Radiologically osteophyte formation can be assessed by Nathan' ${ }^{3}$ classification. If the total number osteophytes from L1/L2 to L5/S1 is more than six, that patient is considered osteophyte positive. If it is less than six, the patient is considered as osteophyte negative.

Suprapaneni et al. ${ }^{18}$ stated reactive oxygen species are involved in age related degenerative diseases' pathophysiology.

Cells within joint produce reactive oxygen species which are involved in oxidative damage to joint and osteophyte formation. ${ }^{18}$

Serum beta carotene is a carotenoid which has antioxidant effect by increasing Gluthione levels in cells. ${ }^{31-33}$ Beta carotene had an effect halting the progression of many diseases cardio vascular and reducing lung cancer risk. ${ }^{37-39}$ It also halts the progression of degenerative changes in Knee joint. As an antioxidant it removes singlet oxygen, scavenges peroxyl and hydroxyl radicals as well as inactivating anionic super oxide compounds. ${ }^{34-36}$

The normal serum beta carotene level ranges from $0.74 \mathrm{nmol} / \mathrm{ml}$ to $3.72 \mathrm{nmol} / \mathrm{ml}$. Human ELISA Kit can access serum beta carotene level.

Many literature studies showed that there is relation between serum beta carotene levels and the formation of osteophytes in degenerative joint disease. Mc Alindon et al. ${ }^{40}$ a co-hort study, Rose et $\mathrm{al}^{41}$ showed that there is the association between degenerative osteophytes formation of the Knee joint and serum beta carotene levels.

Only Imgama et $\mathrm{al}^{4}$ studied the association of the level of serum beta carotene and lumbar osteophyte 
formation. He found that low serum beta carotene levels might cause lumbar osteophyte formation.

There is no other study co-relating the level of serum beta carotene and lumbar degenerative osteophyte formation. Hence this study undertaken.

Imagama also studied the co-ration between the alcohol intake and tobacco consumption. That study showed that there is a strong co-relation of degenerative joint changes with alcohol consumption and tobacco usage.

Here, we studied this too.

\section{Materials and Methods}

153 patients, aged above 50 years who came to the OPD of JIPMER Orthopaedic Department from August 2015 to March 2017 were studied. All of them all complained of chronic low back pain of more than 3 months duration.

Along with the routine demographic data of patients (Name, Age, Sex, Occupation, etc..,) history of Tobacco use (10 cigarettes per day x 5 days) and Alcohol consumption (3 - 4 larges per day $\mathrm{x} 5$ years) were noted. X-Rays of Lumbar Spine: A.P. and Lateral views were taken. Patients with structural and anatomical defects in the Lumbo-sacral spine like spondylolisthesis, scoliosis were excluded from the study.

Once the patient was included in the study $2 \mathrm{ml}$ of blood was taken for routine investigation of TC, DC, ESR, HB. The blood was centrifuged and the serum was collected, labelled and stored in the Bio-Chemistry department for analysis of serum beta carotene.

After completion of sample size of 153 patients, the serum beta carotene levels of these 153 patient were analysed by two Human ELISA 96 strip well kit (Bioassay co.)

All the 153 patients' X-Rays of lumbar spine were reviewed by a single radiologist. If more than 6 osteophytes were observed from L1 to L5 that patient was considered to be osteophyte positive. Patients with less than 6 osteophytes from L1 to L5 were considered as osteophyte negative (Nathan, 1962) ${ }^{3}$

The expected mean and standard deviation of the level of serum beta carotene in Low back pain patients is 0.55 with standard deviation of 0.38 and the sample size is estimated at $5 \%$ of significance and $11 \%$ relative precision.

Inferential and descriptive statistical analyses were carried out in the present study. Results on continuous measurements were shown on Mean SD (Min - Max) and the results of categorical measurements were presented in numbers. The significance was ascessed at $5 \%$ level of significance.

Student ' $\mathrm{t}$ ' test (two tailed, independent) was used to find the significance of study parameters, on continuous scale.

Chi-square / Fischer Exact test was used to find the significance of study parameters on categorical scale. $\mathrm{P}$ value: $0.05<\mathrm{P}<0.10$ significant
$P$ value: $0.05<P<0.05$ moderately significant

$\mathrm{P}$ value: $0.05<\mathrm{P}<0.01$ strongly significant

\section{Results}

All the 153 are from South India. It was conducted from August 2015 to March 2017.

Majority of patients were in the 50-60 years age group $(64.7 \%)$ followed by $61-70$ years $(30.1 \%), 71-80$ years $(4.6 \%)$ and above 80 years $(0.7 \%)$.

Table 1

\begin{tabular}{|l|c|c|}
\hline $\begin{array}{l}\text { Age in } \\
\text { years }\end{array}$ & $\begin{array}{c}\text { Number of } \\
\text { patients }\end{array}$ & Percentage \\
\hline $50-60$ & 99 & $64.7 \%$ \\
\hline $60-70$ & 46 & $30.1 \%$ \\
\hline $70-80$ & 7 & $4.6 \%$ \\
\hline$>80$ & 1 & $0.7 \%$ \\
\hline Total & 153 & $100 \%$ \\
\hline
\end{tabular}

A little more than two thirds $(68 \%)$ were females and rest $(32 \%)$ males.

50 patients in the study group (33\%) were osteophyte positive, of which 22 were $(44 \%)$ males and 28 were $(44 \%)$ males and 28 were $(56 \%)$ females.

Of the 49 males (100\%) 22 were osteophyte positive (45\%). Of the 104 females (100\%). 28 were osteophyte positive $(27 \%)$ suggested male predominance in osteophyte formation.

Table 2: Osteophyte association with gender

\begin{tabular}{|l|c|c|c|}
\hline & Osteohyte & Osteophyte & Total \\
\hline Male & $22(44.89 \%)$ & $27(55.11 \%)$ & $\begin{array}{c}49 \\
(100 \%)\end{array}$ \\
\hline Female & $28(26.93 \%)$ & $76(73.07 \%)$ & $\begin{array}{c}104 \\
(100 \%)\end{array}$ \\
\hline
\end{tabular}

Serum Beta Carotene Levels: The normal serum beta carotene values are from $0.7 \mathrm{nmol} / \mathrm{mL}$ to $3.72 \mathrm{nmol} / \mathrm{mL}$.

Out of the 104 female patients $22 \%$ had less than 0.7 $\mathrm{nmol} / \mathrm{mL}$ serum beta carotene level and $78 \%$ had more than $0.7 \mathrm{nmol} / \mathrm{mL}$.

Among the 49 male patients $32 \%$ had less than 0.7 $\mathrm{nmol} / \mathrm{mL}$ of serum beta carotene level and $68 \%$ had more than $0.7 \mathrm{nmol} / \mathrm{ml}$.

Table 3: Gender distribution serum beta carotene

\begin{tabular}{|l|c|c|c|}
\hline \multicolumn{1}{|c|}{ Serum Beta } & & & \\
\hline Carotene & Female & Male & Total \\
\hline (NMOL/ML) & & & \\
\hline$<0.7$ (Low) & $23(59 \%)$ & $16(41 \%)$ & 39 \\
\hline$>0.7$ (Normal) & $81(71 \%)$ & $33(29 \%)$ & 114 \\
\hline
\end{tabular}

The association of serum beta carotene and lumbar osteophyte formation was studied. Among the 50 osteophyte positive patients, 39 patients $(74 \%)$ had serum beta carotene less than $0.7 \mathrm{nmol} / \mathrm{mL}$ and 13 
patients $(26 \%)$ had serum beta carotene more than 0.7 $\mathrm{nmol} / \mathrm{mL}$.

Out of 103 patients of osteophyte negative group only 2 patients $(02 \%)$ had less than $0.7 \mathrm{nmol} / \mathrm{ml}$ and 101 patients $(98 \%)$ had more than $0.7 \mathrm{nmol} / \mathrm{mL}$ of serum beta carotene levels. This is statistically significant with $\mathrm{P}$ value of 0.0001 .

Table 4: Association of beta carotene and lumbar osteophyte

\begin{tabular}{|l|c|c|}
\hline \multicolumn{1}{|c|}{ Beta carotene } & Osteophyte & Osteophyte \\
\hline NMOL/ML & Negative $<6$ number & Positive $>6$ number \\
\hline$<0.7$ & $2(2 \%)$ & $37(74 \%)$ \\
\hline $0.7-2.8$ & $101(98 \%)$ & $13(26 \%)$ \\
\hline Total & 103 & 50 \\
\hline
\end{tabular}

The correlation between serum beta carotene and lumbar osteophyte was studied. There is moderate correlation between lumbar osteophytes formation with serum beta carotene level ( $\mathrm{r}=-0.5822)$ which is statistically significant $(\mathrm{p}<0.0001)$.

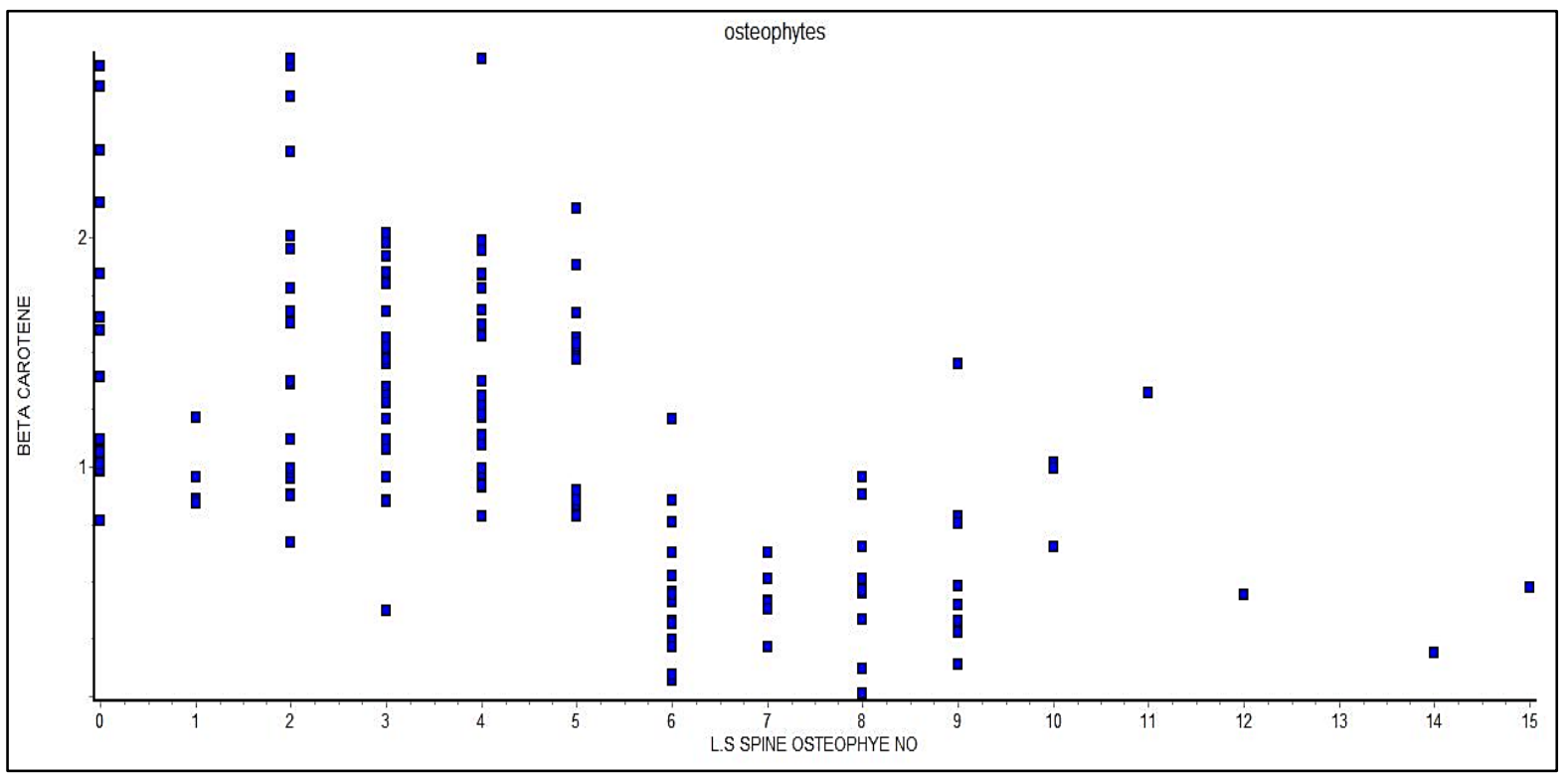

Fig. 4: Correlation between serum beta carotene and lumbar osteophyte

The relationship between Tobacco consumption and Lumbar osteophyte formation was studied. Of the 50 osteophytes positive patients $44 \%$ were Tobacco consumers. Of the 103 osteophyte negative patients majority (84\%) were non Tobacco consumers. These statistics show that there is a strong association between Tobacco consumption and lumbar osteophyte formation which is reflected in the significant $P$ value of 0.001 .

Table 5: Tobacco consumption and osteophyte relation

\begin{tabular}{|l|c|c|}
\hline & Osteophyte negative & Osteophyte positive \\
\hline Non tobacco consumers & $87(84 \%)$ & $28(56 \%)$ \\
\hline Tobacco consumers & $16(16 \%)$ & $22(44 \%)$ \\
\hline Total & 103 & 50 \\
\hline
\end{tabular}

The relationship between alcohol consumption and lumbar osteophyte was also studied. Of the 103 osteophyte negative patients $84 \%$ were non-alcoholic.
Of the 50 osteophyte positive patients $62 \%$ were non alcoholics. With a $\mathrm{P}$ value of 0.003 , relatively less significant compared to other variables.

Table 6: Association of alcohol and osteophyte formation

\begin{tabular}{|l|c|c|}
\hline & Osteophyte negative & Osteophyte positive \\
\hline Non alcoholics & $86(84 \%)$ & $31(62 \%)$ \\
\hline Alcoholics & $17(16 \%)$ & $19(38 \%)$ \\
\hline Total & 103 & 50 \\
\hline
\end{tabular}




\section{Discussion}

This study was undertaken to identify the relationship between the level of serum beta carotene and the formation of lumbar osteophytes in patients older than 50 years.

Literature showed only one study by Imagma et al (2005) who studied the relationship of serum beta carotene and lumbar osteophytes in 286 patients of over 50 years of age. With a mean age of 68 years.

Our study had 153 patients with the mean age of 59 years.

Imagama et al observed that men had significantly more lumbar osteophyte positivity than women. In our study we found men had more osteophyte positivity with $44 \%$ of all male patients had osteophyte positivity whereas only $27 \%$ of all female patients had osteophyte positivity.

Out of 153 patients we studied $34 \%$ had serum beta carotene less than $0.7 \mathrm{nmol} / \mathrm{mL}$. Among the 50 osteophyte positive patients $74 \%$ had less than 0.7 $\mathrm{nmol} / \mathrm{mL}$ of serum beta carotene.

In our study the average serum beta carotene levels in osteophyte positive patients is $0.516+/-0.327$ $\mathrm{nmol} / \mathrm{mL}$ and among osteophyte negative patients is $1.454+/-0.521 \mathrm{nmol} / \mathrm{mL}$ with $\mathrm{P}$ value $<0.001$ which is statistically significant.

The study of Imagama et al indicated that the serum beta carotene level and lumbar osteophyte formation are inversely correlated. Our results are in agreement with his study.

In spite of the geographical remoteness between the locations of these two studies, the average serum beta carotene levels had almost equal values in osteophyte positive patients. This may indicate a common reference range of this particular parameter which may have the potential to be used as a criterion for pre-emptive diagnosis of impending degenerative lumbar Spine disease. This requires more studies as to whether usage of beta carotenoid will stop the progression of lumbar degenerative disease.

The results of our study showed that association of Tobacco consumption and lumbar osteophyte formation is more significant with a $\mathrm{P}$ value of 0.001 compared to the association of alcohol and lumbar osteophyte formation with $\mathrm{P}$ value of 0.033 .

But Imagama et al study showed $80 \%$ of smokers had no osteophytes and only $20 \%$ had osteophyte positivity with a $\mathrm{P}$ value of 0.247 which is not significant.

Our results are in accordance with Imagama et al study with respect to alcohol and lumbar osteophyte association. But our study found that the association is stronger with Tobacco consumption than alcohol intake.

\section{Conclusion}

Our study was limited as we did not study other anti - oxidants other than beta carotene. Further our study did not include other factors of lumbar spine degeneration like Body Mass Index, Lordosis, etc.

From the results of our study we conclude that low serum beta carotene levels is associated with lumbar osteophyte formation.

Tobacco consumption to a more level and Alcohol intake to a lesser level predisposes to lumbar osteophyte formation.

From our study suggest that dietary supplements of beta carotene may present the progression of lumbar osteophyte formation.

\section{References}

1. Van Geen J-W, Edelaar MJA, Janssen M, van Eijk JTM. The longterm effect of multidisciplinary back training: a systematic review. Spine. 2007;32(2):249-55.

2. O’Neill TW, McCloskey EV, Kanis JA, Bhalla AK, Reeve J, Reid DM, et al. The distribution, determinants, and clinical correlates of vertebral osteophytosis: a population based survey. J Rheumatol. 1999;26(4):842$8 .$.

3. Nathan M, Pope MH, Grobler LJ. Osteophyte formation in the vertebral column: a review of the etiologic factorsPart II. Contemp Orthop. 1994;29(2):113-9.

4. Imagama S, Hasegawa $Y$, Seki T, Matsuyama $Y$, Sakai $\mathrm{Y}$, Ito $\mathrm{Z}$, et al. The effect of $\beta$-carotene on lumbar osteophyte formation. Spine. 2011;36(26):2293-8

5. Machlin LJ, Bendich A. Free radical tissue damage: protective role of antioxidant nutrients. FASEB J Off Publ Fed Am Soc Exp Biol. 1987;1(6):441-5.

6. Dillane JB, Fry J, Kalton G. Acute back syndrome-a study from general practice. Br Med J. 1966;2(5505):824.

7. Cedraschi C, Robert J, Goerg D, Perrin E, Fischer W, Vischer TL. Is chronic non-specific low back pain chronic? Definitions of a problem and problems of a definition. Br J Gen Pract J R Coll Gen Pract. 1999;49(442):358-62.

8. Macfarlane GJ, Thomas E, Papageorgiou AC, Croft PR, Jayson MI, Silman AJ. Employment and physical work activities as predictors of future low back pain. Spine. 1997;22(10):1143-9.

9. Lawrence JS. Disc degeneration. Its frequency and relationship to symptoms. Ann Rheum Dis. 1969;28(2):121-38.

10. Kellgren JH, Lawrence JS. Osteo-arthrosis and disk degeneration in an urban population. Ann Rheum Dis. 1958;17(4):388-97.

11. Torgerson WR, Dotter WE. Comparative roentgenographic study of the asymptomatic and symptomatic lumbar spine. J Bone Joint Surg Am. 1976;58(6):850-3.

12. Frymoyer JW, Newberg A, Pope MH, Wilder DG, Clements J, MacPherson B. Spine radiographs in patients with low-back pain. An epidemiological study in men. $J$ Bone Joint Surg Am. 1984;66(7):1048-55.

13. Lane NE, Nevitt MC, Genant HK, Hochberg MC. Reliability of new indices of radiographic osteoarthritis of the hand and hip and lumbar disc degeneration. $J$ Rheumatol. 1993;20(11):1911-8.

14. Pye SR, Reid DM, Lunt M, Adams JE, Silman AJ, O'Neill TW. Lumbar disc degeneration: association between osteophytes, end-plate sclerosis and disc space narrowing. Ann Rheum Dis. 2007;66(3):330-3. 
15. Van der Kraan PM, van den Berg WB. Osteophytes: relevance and biology. Osteoarthr Cartil OARS Osteoarthr Res Soc. 2007;15(3):237-44.

16. Fardon DF, Milette PC, Combined Task Forces of the North American Spine Society, American Society of Spine Radiology, and American Society of Neuroradiology. Nomenclature and classification of lumbar disc pathology. Recommendations of the Combined task Forces of the North American Spine Society, American Society of Spine Radiology, and American Society of Neuroradiology. Spine. 2001;26(5):E93-113.

17. Schneck CD. The anatomy of lumbar spondylosis. Clin Orthop. 1985;(193):20-37.

18. Surapaneni KM, Venkataramana G. Status of lipid peroxidation, glutathione, ascorbic acid, vitamin E and antioxidant enzymes in patients with osteoarthritis. Indian J Med Sci. 2007;61(1):9-14.

19. Shirasawa S, Sekiya I, Sakaguchi Y, Yagishita K, Ichinose S, Muneta T. In vitro chondrogenesis of human synovium-derived mesenchymal stem cells: optimal condition and comparison with bone marrow-derived cells. J Cell Biochem. 2006;97(1):84-97.

20. Sakaguchi Y, Sekiya I, Yagishita K, Muneta T. Comparison of human stem cells derived from various mesenchymal tissues: superiority of synovium as a cell source. Arthritis Rheum. 2005 Aug;52(8):2521-9.

21. Uchino M, Izumi T, Tominaga T, Wakita R, Minehara H, Sekiguchi M, et al. Growth factor expression in the osteophytes of the human femoral head in osteoarthritis. Clin Orthop. 2000;(377):119-25.

22. 22.Blaney Davidson EN, Vitters EL, van der Kraan PM, van den Berg WB. Expression of transforming growth factor-beta (TGFbeta) and the TGF beta signalling molecule SMAD-2P in spontaneous and instability induced osteoarthritis: role in cartilage degradation, chondrogenesis and osteophyte formation. Ann Rheum Dis. 2006;65(11):1414-21.

23. Okazaki K, Jingushi S, Ikenoue T, Urabe K, Sakai H, Ohtsuru A, et al. Expression of insulin-like growth factor I messenger ribonucleic acid in developing osteophytes in murine experimental osteoarthritis and in rats inoculated with growth hormone-secreting tumor. Endocrinology. 1999;140(10):4821-30.

24. Iwasaki M, Nakahara H, Nakata K, Nakase T, Kimura T, Ono K. Regulation of proliferation and osteochondrogenic differentiation of periosteum-derived cells by transforming growth factor-beta and basic fibroblast growth factor. J Bone Joint Surg Am. 1995;77(4):543-54.

25. Martin JA, Buckwalter JA. Roles of Articular Cartilage Aging and Chondrocyte Senescence in the Pathogenesis of Osteoarthritis. Iowa Orthop J. 2001;21:1-7.

26. Sandell LJ, Aigner T. Articular cartilage and changes in Arthritis: Cell biology of osteoarthritis. Arthritis Res. 2001;3(2):107-13.

27. Blom AB, van Lent PLEM, Holthuysen AEM, van der Kraan PM, Roth J, van Rooijen N, et al. Synovial lining macrophages mediate osteophyte formation during experimental osteoarthritis. Osteoarthr Cartil OARS Osteoarthr Res Soc. 2004;12(8):627-35.

28. Von Zglinicki T. Oxidative stress shortens telomeres. Trends Biochem Sci. 2002;27(7):339-44.

29. Loeser RF, Carlson CS, Del Carlo M, Cole A. Detection of nitrotyrosine in aging and osteoarthritic cartilage: Correlation of oxidative damage with the presence of interleukin-1beta and with chondrocyte resistance to insulin-like growth factor 1. Arthritis Rheum. 2002;46(9):2349-57.

30. Van Beuningen HM, Glansbeek HL, van der Kraan PM, van den Berg WB. Differential effects of local application of BMP-2 or TGF-beta 1 on both articular cartilage composition and osteophyte formation. Osteoarthr Cartil OARS Osteoarthr Res Soc. 1998;6(5):306-17.

31. Castenmiller JJ, West CE. Bioavailability and bioconversion of carotenoids. Annu Rev Nutr. 1998;18:19-38.

32. Djuric Z, Ren J, Blythe J, VanLoon G, Sen A. A Mediterranean dietary intervention in healthy American women changes plasma carotenoids and fatty acids in distinct clusters. Nutr Res N Y N. 2009 Mar;29(3):15663.

33. Yonekura L, Nagao A. Intestinal absorption of dietary carotenoids. Mol Nutr Food Res. 2007 Jan;51(1):107-15.

34. Bach-Faig A, Geleva D, Carrasco JL, Ribas-Barba L, Serra-Majem L. Evaluating associations between Mediterranean diet adherence indexes and biomarkers of diet and disease. Public Health Nutr. 2006 Dec;9(8A):1110-7.

35. Burton GW, Ingold KU. beta-Carotene: an unusual type of lipid antioxidant. Science. 1984 May 11;224(4649):569-73.

36. Park CK, Ishimi Y, Ohmura M, Yamaguchi M, Ikegami S. Vitamin A and carotenoids stimulate differentiation of mouse osteoblastic cells. J Nutr Sci Vitaminol (Tokyo) 1997;43:281-296.

37. Seddon J.M., Ajani U.A., Sperdulo R.D., Hiller R., Blair N., Burton T.C., Farber M.D., Gragousdos E.S., Haller J., Miller D.T., Yannuzzi L.A., Willetti W., for the Eye Disease Case-Control Study Group.(1994)dietary car0tenoids, vitamins A C, and E, and advanced age related macular degeneration. J. Am. Med. Assn. 272,1413-1420.

38. Gey K, F., Moser U.K., Jordan P., Stahelin H.B., Eichholzer M., and Liidin E. (1993). Increased risk of cardiovascular disease at suboptimal plasms consentration of essential antioxidants: an epidemiological update with special alteration to carotene and vitamin C. Am. J. Clin. Nutr.57(Suppl.)787S-797S .

39. LeMarchand L., Hankin J.H., Kolonel L.N., Beecher G.R., Wilkens L., R., and Zhao L., P. (1993) Intake of specific carotenoids and lung cancer risk. Cancer Epidimiol, Biomarker \& Prev.2.183-18.

40. McAlindon TE, Jacques P, Zhang Y, Hannan MT, Alibadi P, Weissman B, et al.(1996) Do antioxidant micronutrients protect against the development and progression of knee osteoarthritis Rheum 39:648-656.

41. De Roos AJ, Arab L, Renner JB, Craft N, Luta G, Helmick CG, et al. Serum carotenoids and radiographic knee osteoarthritis: the Johnston County Osteoarthritis Project. Public Health Nutr. 2001 Oct;4(5):935-42.

How to cite this article: Selvam N, Rapeta RB. Level of serum beta carotene and its association with lumbar osteophyte formation. Indian $\mathrm{J}$ Orthop Surg. 2018;4(3):296-301. 